\title{
Cytosolic estrogen and progesterone receptor content in the endometriotic tissues and endometrium in women with and without endometriosis
}

\author{
T.Z. Jacoeb ${ }^{*}$, C. Nuruliza ${ }^{f}$, N. Chaniago ${ }^{f}$
}

\begin{abstract}
Abstrak
Guna memperoleh profil reseptor estrogen dan progesteron sitosol baik di dalam jaringan endometriosis maupun endometrium pada pasien dengan atau tanpa endometriosis dilakukan suatu kajian iris-silang yang melibatkan 43 wanita infertil. Ini terdiri dari 31 (72,09\%) kasus endometriosis dan 12 (27,91\%) kasus nir-endometriosis; umur rerata masing-masing $32 \pm 4$ tahun dan $32 \pm 3$ tahun, dengan rerata panjang siklus haid masing-masing $31 \pm 8$ hari dan $29 \pm 1$ hari. Jaringan endometriosis diperoleh dengan eksisi selama tindakan laparoskopi operatif, sementara endometrium diperoleh dengan biopsi menyusul tindakan histeroskopi. Tindakan ini dilaksanakan dalam kurun periovulasi (Hari 13-18 siklus haid). Kandungan reseptor steroid seks dalam sitosol diukur secara kuantitatif menggunakan cara tera imunoenzimatik, dan dihitung sebagai reseptor steroid seks/protein sitosol (fmol/ml sitosol). Ditemukan bahwa konsentrasi rerata reseptor estrogen sitosol dalam jaringan terkait adalah: 512.99 fmol/ml di ovarium endometriotik dibandingkan dengan $2369.17 \mathrm{fmol} / \mathrm{ml}$ di ovarium normal, dan $601.02 \mathrm{fmol} / \mathrm{ml}$ di peritoneum endometriotik dibandingkan dengan $9607.61 \mathrm{fmol} / \mathrm{ml}$ di peritoneum normal, serta masing-masing $99.28 \mathrm{fmol} / \mathrm{ml} \mathrm{dan} 608.33 \mathrm{fmol} / \mathrm{ml} \mathrm{di}$ endometrium wanita dengan dan tanpa endometriosis. Konsentrasi rerata reseptor progesteron sitosol yang ditemukan di masingmasing jaringan adalah $50.64 \mathrm{fmol} / \mathrm{ml}$ di ovarium endometriotik dibandingkan $6496.42 \mathrm{fmol} / \mathrm{ml}$ di ovarium normal dan 1631.40 $\mathrm{fmol} / \mathrm{ml}$ di peritoneum endometriotik dibandingkan $12466.99 \mathrm{fmol} / \mathrm{ml}$ di peritoneum normal, serta masing-masing $21.26 \mathrm{fmol} / \mathrm{ml}$ dan $599.61 \mathrm{fmol} / \mathrm{ml}$ di endometrium wanita dengan dan tanpa endometriosis. Tidak terdapat perbedaan bermakna pada konsentrasi reseptor antara masing-masing jaringan menurut asal to-pografiknya. Namun demikian, hasil ini dapat memperkirakan bahwa dayatanggap terhadap penanganan hormonal pada kasus-kasus endometriosis akan bergantung pada kandungan reseptor steroid seks sitosol pada jaringan yang sakit, dan lesi-lesi peritoneal mungkin akan memberikan tanggapan yang lebih baik daripada yang di sisi lain. Diperlukan uji klinis lebih lanjut. (Med J Indones 2005; 14: 133-41)
\end{abstract}

\begin{abstract}
In order to have a profile of cytosolic estrogen and progesterone receptors in either endometriotic tissue or endometrium in patients with and without endometriosis a cross-sectional study was performed involving 43 infertile women. They consisted of 31 (72.09\%) en-dometriosis and 12 (27.91\%) non-endometriosis cases; their average age was $32 \pm 4$ years and $32 \pm 3$ years respectively, with the ave-rage length of menstrual cycle $31 \pm 8$ days and $29 \pm 1$ days respectively. The endometriotic tissue was obtained by excision during ope-rative laparoscopy procedure, while the endometrium was obtained by biopsy following hysteroscopy procedure. These procedures were conducted within the periovulatory period (on Day 13-18 of the cycle). The sex steroid receptor content in the cytosol was measured quantitatively using enzyme-immunoassay method, and calculated as sex steroid receptor/cytosol protein (fmol/ml cytosol). It was found that the average cytosolic estrogen receptor concentration in the respective tissues were 512.99 $\mathrm{fmol} / \mathrm{ml}$ in the endometriotic ovary compared with 2369.17 in normal ovary and $632.18 \mathrm{fmol} / \mathrm{ml}$ in the endometriotic peritoneum compared with $9607.61 \mathrm{fmol} / \mathrm{ml}$ in normal peritoneum; while $99.28 \mathrm{fmol} / \mathrm{ml}$ and $608.33 \mathrm{fmol} / \mathrm{ml}$ in the endometrium of women with endometriosis and those without endometriosis respectively. The average cytosolic progesterone receptor concentration found in the respective tissues were $50.64 \mathrm{fmol} / \mathrm{ml}$ in the endometriotic ovary compared with $6469.42 \mathrm{fmol} / \mathrm{ml}$ in normal ovary and 1631.40 $\mathrm{fmol} / \mathrm{ml}$ in endometriotic peritoneum compared with 12466.99 in normal peritoneum, while $21.26 \mathrm{fmol} / \mathrm{ml} \mathrm{and} 599.61 \mathrm{fmol} / \mathrm{ml}$ in the endometrium of women with endometriosis and those without endometriosis respectively. There is no significant difference in the receptor concentration between each tissue according to its topographic origin. However, this result may assume that the responsivity on hormonal treatment in endometriosis cases will depend on the cytosolic sex steroid receptor content in the sick tissues, and the peritoneal lesions will possibly give better response than those in other sites. A further clinical trial is necessary. (Med J Indones 2005; 14: 133-41)
\end{abstract}

Keywords: Estrogen, progesterone, receptor, cytosol, endometriosis, endometrium, infertile

\footnotetext{
* Division of Reproductive Immunoendocrinology, Department of Obstetrics and Gynecology, Faculty of Medicine University of

Indonesia, Jakarta, Indonesia

${ }^{f}$ Endocrinology Laboratory, Research Center for Immunoendocrinology, Faculty of Medicine University of Indonesia, Jakarta, Indonesia
} 
Endometriosis is still believed as the presence of an endometrium-like tissue outside of the uterine cavity. It is a common gynecological condition affecting 1 in 10 women in the reproductive age group. ${ }^{1}$ Its incidence increases to $20 \%$ in patients with infertility and up to $30 \%$ in patients with chronic pelvic pain. ${ }^{2}$ Furthermore, endometriosis develops mostly in women of reproductive age and regresses after menopause or ovariectomy, suggesting that its existence is influenced by ovarian steroid hormones (estrogen and progesterone). Estrogen leads to the process of growth (estrogendependent), ${ }^{3}$ while progesterone facilitates the process of suppression or shrinkage of the endometriotic tissues.

Although the etiology and the exact mechanism for the development of endometriosis are still unresolved, there is a large body of laboratory and circumstantial evidence that suggests an important role for estrogen in the establishment and maintenance of this disease. On the other hand, proliferation and differentiation of the human endometrium are also controlled by ovarian sex steroids. Estrogen stimulates the proliferation of both glandular and stromal cells, whereas progesterone inhibits the growth of glandular cells and induces decidual changes in stromal cells. ${ }^{4}$ Hormone-induced proliferation and differentiation of the endometrium have been investigated from various aspects, including up- and down-regulation of steroid receptors. ${ }^{4,5}$ The sex steroid-induced events are generally believed to occur via estrogen receptors (ER) and progesterone receptors (PR), which eventually promote the transcription of target genes. ${ }^{5}$

The existence of sex steroid hormone receptors, either in endometrium or endometriosis, can be detected by using either semiquantitative but more specific (such as immunohistochemistry) or quantitative (such as enzyme immunosorbent assay) methods. Using those both techniques, endometriosis tissue had also been demonstrated to express estrogen and progesterone receptors. ${ }^{6,7}$ These receptors have showed heterogeneity of different sites. ${ }^{8}$ Despite a sensitive and specific tool, the semi-quantitative technique does not measure the receptor concentration in the endometriotic tissue, which can even be used as a quantitative parameter of responsivity to the medical treatment given.

When the response of the steroid sex-dependent tissues to hormonal therapy is concerned, it is clearly seen that indicators of the response of endometrial tissue to ovarian steroid hormones were different between endometrium and endometriosis. Histological and ultrastructural studies have demonstrated that endometriosis responded in an incomplete and variable fashion, compared with endometrium, to cyclic estrogen and progesterone stimulation and also to hormonal therapy. ${ }^{9,10}$

The dependency of endometriosis on sex steroid hormones has rationalized to use drugs for endometriosis treatment those with the ability in modulating or in opposing the action of those sex hormones. Frequently, despite maximal hormonal treatment, however, a good response is failed to achieve. It may be caused by either the presence or absence and the content of estrogen and progesterone receptors in those abnormal tissues.

The objective of this study was to measure the concentration of estrogen and progesterone receptors and to compare their concentration between those in the normal and those in endometriotic tissues according to the anatomical topographic location of internal genital organ. This investigation was designed as a cross-sectional and analytical study.

\section{METHODS}

\section{Subject selection}

This study was conducted from February 1995 until July 1996 at the Budhi Jaya Maternity Hospital, Jakarta (as sample collecting site) and the Endocrine Laboratory, Research Center for Immunoendocrinology, Faculty of Medicine University of Indonesia, Jakarta. The subjects enrolled in this study were 43 infertile women undergoing infertility work-up at the level of diagnostic and/or operative gynecologic endoscopy. They consisted of $31(72.09 \%)$ with endometriosis and $12(27.91 \%)$ with normal laparoscopic finding. The mean $( \pm$ SD) ages were $32 \pm 4$ years and $32 \pm 3$ years in endometriosis and normal patients respectively, while their mean length of menstrual cycles were $31 \pm$ 8 days and $29 \pm 1$ days in endometriosis and normal patients respectively.

\section{Samples}

The endometriotic tissue was obtained by excision during operative laparoscopy procedure, while the endometrium was obtained by biopsy following 
hysteroscopy procedure prior to laparoscopy. These both procedures were conducted within the periovulatory period (on Day 13-18 of the cycle).

A total of 73 samples was examined, which were divided into six groups, i.e. $12(16.44 \%)$ endometrium of normal patients, $28(38.36 \%)$ endometrium of endometriotic patients, $5(6.85 \%)$ ovary of normal patients, $16(21.92 \%)$ ovary of endometriotic patients, $3(4.11 \%)$ peritoneum of normal patients, and $9(12.33 \%)$ peritoneum of endometriosis patients. This grouping was based on the presence or absence of endometriosis and the tissue site of origin. The accuracy of the tissue type was confirmed by histopathological findings.

\section{Laboratory protocols}

After having collected in the operating theatre the tissues were washed with physiologic saline to remove the blood, and then they were immediately sent to the laboratory in cool condition $\left(4^{\circ} \mathrm{C}\right)$. The tissues can be either directly processed for homogenization or stored freeze at minus $20 \mathrm{oC}$ before homogenization.

Prior to homogenization the tissues were cleansed and then cut into tiny parts, which were further diluted to 10 times volume in the homogenization buffer. The process of homogenization was performed in a cool condition for 15 minutes. The homogenized tissue was centrifugated for 10 minutes at $1,000 \mathrm{G}$ to separate the supernatant from the tissue matrix. The supernatant was centrifugated for 20 minutes at $10,000 \mathrm{~g}$ to separate the big-size protein, such as mitochondria, lysosome, etc. This was followed by the second centrifugation of the supernatant for 2 hours at $100,000 \mathrm{G}$ to precipitate the small-size protein. The upper layer containing the cytosol protein was finally taken to measure its concentration of cytosol fraction protein using Lowry method. ${ }^{11}$

The receptor concentration was measured quantitatively with enzyme immunosorbent assay (EIA) method using estrogen and progesterone receptor kits (Abbott ER and PR EIA monoclonal, Abbott Laboratories, USA).

\section{Cytosolic receptor calculation}

The cytosolic receptor concentration was calculated as sex steroid receptor/cytosol protein ( $\mathrm{fmol} / \mathrm{ml}$ cytosol) using the following formula: fmol receptor $/ \mathrm{mg}$ cytosol protein $=\frac{\text { fmolreceptor } / \mathrm{mLcytosol}}{\text { mgprotein } / \mathrm{mLcytosol}}$

The result was stated as positive if the concentration was $>15$ and negative if the concentration was $\leq 15$.

\section{Statistical analysis}

The receptor value was expressed as mean \pm SE. Comparisons of the means of receptors were performed by the $X^{2}$-test. The test was stated as significant if the $p$ value is less than 0.05 .

\section{RESULTS}

\section{Cytosolic estrogen receptor content}

The endometrium in normal patients demonstrated 83.33\% (10/12 samples) positive value of ERc, with the mean $( \pm$ SE) $608.33( \pm 347.09) \mathrm{fmol} / \mathrm{mg}$ cytosol protein (Table 1.). The endometrium in endometriosis patients had $35.71 \%$ (10/28 samples) positive value of this receptor, with the mean $( \pm$ SE) $99.28( \pm 70.02)$ fmol/mg cytosol protein.

In the normal ovarian and peritoneal tissues, $100 \%$ (5/5 and 3/3 samples) positive value was found. The ERc mean concentration $( \pm$ SE) in each tissue was $2369.17( \pm 1586.58)$ and 9607.61 ( \pm 6713.84) $\mathrm{fmol} / \mathrm{mg}$ cytosol protein of ovarian and peritoneal samples respectively.

The endometriotic tissues (ovary and peritoneum) had $64 \%$ (16/25 samples) positive value, or $62.5 \%(10 / 16)$ for ovarian samples and $77.78 \%$ (7/9) for peritoneal samples respectively, with the mean $( \pm$ SE) ERc concentration in each tissue was 512.99 ( \pm 271.13) and $601.02( \pm$ 232.27) $\mathrm{fmol} / \mathrm{mg}$ cytosol protein respectively.

Table 1 shows clearly that normal tissues contain higher ERc than endometriotic tissues matched with their topographic sites. The ratio of ERc in normal / endometriotic tissues according to their topographic origin are successively 6.13 in endometrium, 4.62 in ovary, and 15.99 in peritoneum. This evident suggests that the ERc highest ratio is expressed by the peritoneum. 


\section{Cytosolic progesterone receptor content}

The endometrium in normal patients demonstrated $75 \%$ (9/12 samples) positive value of PRc, with the mean $( \pm$ SE) $599.61( \pm$ 383.40 $) \mathrm{fmol} / \mathrm{mg}$ cytosol protein (Table 2.). The endometrium in endometriosis patients had $35.71 \%$ (10/28 samples) positive value of this receptor, with the mean $( \pm$ SE) 21.26 ( \pm 6.17) $\mathrm{fmol} / \mathrm{mg}$ cytosol protein.

In the normal ovarian and peritoneal tissues, $100 \%$ (5/5 and 3/3 samples) positive value was found. The PRc mean concentration $( \pm$ SE) in each tissues was $6496.42( \pm 5224.45)$ and $12466.99( \pm 7901.56) \mathrm{fmol} / \mathrm{mg}$ cytosol protein of ovary and peritoneum respectively.

The endometriotic tissues (ovary and peritoneum) had $44 \%$ (11/25 samples) positive value, or $43.75 \%$ (7/16) for ovarian samples and $44.44 \%$ (4/9) for peritoneal samples respectively, with the PRc mean (( \pm SE) concentration in each tissue was $512.99( \pm 271.13)$ and $601.02( \pm 232.27) \mathrm{fmol} / \mathrm{mg}$ cytosol protein respectively.

Table 2 also shows clearly that the normal tissues contain higher PRc than the endometriotic tissues matched with their topographic sites. The ratio of PRc in the normal/endome triotic tissues according to their topographic origin are successively 28.20 in endometrium, 128.29 in ovary, and 7.64 in peritoneum. This evident suggests that the PRc highest ratio is expressed by the endometrium.

It is appeared that the normal endometrium contains PRc 4.6-folds higher than ERc, whereas the normal ovary contains PRc 27.8-folds higher than ERc. However, the normal peritoneum contains ERc 2.2-folds higher than PRc.

Table 1. Percentage and mean concentration $( \pm$ SE) of cytosolic estrogen receptor (ERc) in endometriotic and normal tissues according to its topographic origin

\begin{tabular}{|c|c|c|c|c|c|c|c|}
\hline \multirow{3}{*}{ Cases } & \multirow{3}{*}{ Tissue origin } & \multirow{3}{*}{$\mathrm{n}$} & \multicolumn{5}{|c|}{ Cytosolic estrogen receptor } \\
\hline & & & \multirow{2}{*}{$\mathrm{n}(+)$} & \multirow{2}{*}{$\%(+)$} & $\mathrm{C}$ & $\mathrm{SE}$ & \multirow{2}{*}{$\begin{array}{l}\text { Ratio of ERc in } \\
\text { normal/endometriosis }\end{array}$} \\
\hline & & & & & \multicolumn{2}{|c|}{ (fmol receptor/mg cytosol protein) } & \\
\hline \multirow{3}{*}{$\begin{array}{l}\text { Normal } \\
\mathrm{n}=20\end{array}$} & Endometrium & 12 & 10 & 83.33 & 608.33 & 347.09 & 6.13 \\
\hline & Ovary & 5 & 5 & 100.00 & 2369.17 & 1586.58 & 4.62 \\
\hline & Peritoneum & 3 & 3 & 100.00 & 9607.61 & 6713.84 & 15.99 \\
\hline \multirow{3}{*}{$\begin{array}{l}\text { Endometriosis } \\
\mathrm{n}=53\end{array}$} & Endometrium & 28 & 10 & 35.71 & 99.28 & 70.02 & \\
\hline & Ovary & 16 & 10 & 62.50 & 512.99 & 271.13 & \\
\hline & Peritoneum & 9 & 7 & 77.78 & 601.02 & 232.27 & \\
\hline
\end{tabular}

$\mathrm{n}(+)$ : number of positive receptor; \%(+): percentage of positive receptor; C: mean concentration of the receptor (fmol/ng cytosol) SE: standard error of mean; normal $=$ without endometriosis

Table 2. Percentage and mean concentration $( \pm \mathrm{SE})$ of cytosolic progesterone receptor $(\mathrm{PRc})$ in endometriotic and normal tissues according to its topographic origin

\begin{tabular}{|c|c|c|c|c|c|c|c|}
\hline \multirow{3}{*}{ Cases } & \multirow{3}{*}{ Tissue origin } & \multirow{3}{*}{$\mathrm{n}$} & \multicolumn{5}{|c|}{ Cytosolic progesterone receptor } \\
\hline & & & \multirow{2}{*}{$\mathrm{n}(+)$} & \multirow{2}{*}{$\%(+)$} & $\mathrm{C}$ & $\mathrm{SE}$ & \multirow{2}{*}{$\begin{array}{l}\text { Ratio of PRc in } \\
\text { normal/endometriosis }\end{array}$} \\
\hline & & & & & \multicolumn{2}{|c|}{ (fmol receptor/mg cytosol protein) } & \\
\hline \multirow{3}{*}{$\begin{array}{l}\text { Normal } \\
\mathrm{n}=20\end{array}$} & Endometrium & 12 & 9 & 75.00 & 599.61 & 383.40 & 28.20 \\
\hline & Ovary & 5 & 5 & 100.00 & 6496.42 & 5224.45 & 128.29 \\
\hline & Peritoneum & 3 & 3 & 100.00 & 12466.99 & 7901.56 & 7.64 \\
\hline \multirow{3}{*}{$\begin{array}{l}\text { Endometriosis } \\
\mathrm{n}=53\end{array}$} & Endometrium & 28 & 10 & 35.71 & 21.26 & 6.17 & \\
\hline & Ovary & 16 & 7 & 43.75 & 50.64 & 271.13 & \\
\hline & Peritoneum & 9 & 4 & 44.44 & 1631.40 & 1227.27 & \\
\hline
\end{tabular}

$\mathrm{n}(+)$ : number of positive receptor; \%(+): percentage of positive receptor; C: mean concentration of the receptor (fmol/ng cytosol)

SE: standard error of mean; normal $=$ without endometriosis 


\section{Significancy comparison between each sex steroid receptor in tissues according to its topographic origin}

Significancy test between the sex steroid receptors in endometrium, ovary, and peritoneum of either normal or endometriotic cases showed no significant difference (p>0.05) (Table 3. and Table 4).

Table 3. Comparison of the ERc content in each tissue according to its topographic origin between women without and with endometriosis

\begin{tabular}{lrcc}
\hline \multirow{2}{*}{ Tissue origin } & \multicolumn{2}{c}{ Cases } & \multicolumn{1}{c}{$\begin{array}{c}\text { Significancy } \\
\text { test }\left(X^{2}\right), \mathrm{p}\end{array}$} \\
\cline { 2 - 3 } & Normal & Endometriosis & $>0.05$ \\
Endometrium & 608.33 & 99.28 & $>0.05$ \\
Ovary & 2369.17 & 512.99 & $>0.05$ \\
Peritoneum & 9607.61 & 601.02 & \\
\hline
\end{tabular}

Normal $=$ without endometriosis

Table 4. Comparison between the PRc content in each tissue according to its topographic origin between women without and with endometriosis

\begin{tabular}{lrcc}
\hline \multirow{2}{*}{ Tissue origin } & \multicolumn{2}{c}{ Cases } & Significancy \\
\cline { 2 - 3 } & Normal & Endometriosis & test $\left(X^{2}\right), \mathrm{p}$ \\
\hline Endometrium & 599.61 & 21.26 & $>0.05$ \\
Ovary & 6496.42 & 50.64 & $>0.05$ \\
Peritoneum & 12466.99 & 1631.40 & $>0.05$ \\
\hline
\end{tabular}

Normal $=$ without endometriosis

Table 5 demonstrates that the highest PRc/ERc ratio occurs in the peritoneal tissue. This data suggests that peri-toneum is the most responsive type of sick tissue to the progesterone therapy, while normal ovary is the most af-fected type of normal tissue to the progesterone therapy.

Table 5. Ratio of PRc/ERc content in each tissue according to its topographic origin

\begin{tabular}{|c|c|c|c|}
\hline \multirow{2}{*}{ Tissue origin } & \multicolumn{2}{|c|}{$\mathrm{PRc} / \mathrm{ERc}$ ratio in cases } & \multirow{2}{*}{$\begin{array}{c}\text { Significancy } \\
\text { test }\left(X^{2}\right), p\end{array}$} \\
\hline & Normal & Endometriosis & \\
\hline Endometrium & 0.99 & 0.21 & $>0.05$ \\
\hline Ovary & 2.74 & 0.10 & $<0.05$ \\
\hline Peritoneum & 1.30 & 2.71 & $<0.05$ \\
\hline
\end{tabular}

Normal $=$ without endometriosis

\section{DISCUSSION}

\section{Quantitative versus semi-quantitative assay}

Quantitative differences in the expression of estrogen and progesterone receptors between endometriosis and endometrium can be explained by either a difference in the cellular response of the endometriosis to the steroid hormones or a difference in the biological availability of the steroid to the tissue. ${ }^{12}$ The receptor content measurement is necessary in determining quantitatively the progress of medical treatment through laboratory methods.

Quantitative assays of cytosolic estrogen receptor (ERc) as well as cytosolic progesterone receptor (PRc) have already been performed by some previous investigators ${ }^{7,13}$ in the different tissue origins, and in the different patients. In this study we have also conducted the similar quantitative assay of the abovementioned receptors (ERc and PRc) in tissues of different topographic origin of the same patients with endometriosis, which are then compared with those from normal patients. This method is not done by the previous investigators.

We found that the content of those steroid receptors in the endometriosis tissue is less than that found in the endometrium of the same patient. More specifically, normal tissues contain higher ERc than endometriotic tis-sues matched with their topographic sites. The ratio of ERc in normal/endometriotic tissues according to their topographic origin are successively 6.13 in endometrium, 4.62 in ovary, and 15.99 in peritoneum. This evident suggests that the ERc highest ratio is expressed by the peritoneum (Table 1). Moreover, normal tissues con-tained higher PRc than endometriotic tissues matched with their topographic sites. The ratio of PRc in normal/endometriotic tissues according to their topographic origin are successively 28.20 in endometrium, 128.29 in ovary, and 7.64 in peritoneum. This evident suggests that the PRc highest ratio is expressed by the endometrium (Table 2). Lyndrup et al. $^{7}$ have compared the ERc and PRc content in endometriosis and endometrium using receptor assays and histological examinations. They have detected ERc as well as PRc in $64.3 \%$ and $100 \%$ of cases of endometriosis respectively. Significantly higher values of both ERc and PRc were found in endometrium than endometriosis. A contrast finding was stated by Bergqvist et al. ${ }^{13}$ They found that the endometrial 
receptor concentrations were that same in patients with endometriosis as in the control group because in most cases no receptors could be detected irrespective of the phase of the menstrual cycle.

Interestingly, our results show a lower positive concentration of PRc but a higher positive concentration of ERc compared with the several previous reported studies (Table 7). This may be caused by the difference in the sites of origin of the samples being studied.

\section{Differences of cytosolic steroid receptor content in endometrium and endometriosis tissues}

The concentrations of ERc and PRc in either endometrium or endometriosis tissues are influenced by several factors, including: (1) the phase of menstrual cycle within which the samples are taken; $;^{7,15,18}(2)$ the type of lesion (primary or recurrent), ${ }^{14}$ the sites of origin for samples taken (uterine endometrium, peritoneum, or ovary), ${ }^{7,15}$ and the stage of disease (minimal, mild, moderate, severe); (3) the synchronization of sampling (simultaneously, randomly, or at a different time), ${ }^{15}$ and (4) the sampling procedures (biopsy, excision; laparoscopically or laparotomically) ${ }^{15}$ (Table 6).
The difference of results of ERc as well as PRc in several studies is presented in Table 6 . In the present study we only measure the ERc and PRc in patients with primary endometriosis. Thus, we cannot compare it with recurrent endometriosis. Bergqvist et al ${ }^{14}$ have found that in endometriotic tissue, the PRc level was significantly higher in recurrent than in primary endometriotic tissue, but there was no different concerning ERc. The ERc level was significantly lower in ovarian but not in peritoneal endometriosis, compared with that in endometrium. This is in contrast to our data, which demonstrates that in patients with endometriosis the ERc in the peritoneum is higher than that in either the ovary or endometrium in patients with endometriosis. A difference in the number of samples collected might be the explanation (53 in present study versus 69 in their study). Further, they also stated that no difference was seen concerning PRc either in the endometriotic peritoneum or in the normal peritoneum. However, in the present study we have found a contrast difference in PRc concentration in the peritoneum of women with endometriosis (approximately 35 folds higher) when compared with women without endometriosis.

Table 6. Comparison between the ERc and PRc content (fmol receptor/mg cytosol protein) in patients with and without endometriosis according to factors below as stated by several investigators

\begin{tabular}{|c|c|c|c|c|c|c|c|c|c|c|c|c|}
\hline \multirow{4}{*}{ Comparison according to } & \multicolumn{6}{|c|}{ ERc } & \multicolumn{6}{|c|}{ PRc } \\
\hline & \multicolumn{6}{|c|}{ Site of origin for sampling } & \multicolumn{6}{|c|}{ Site of origin for sampling } \\
\hline & \multicolumn{2}{|c|}{ Endometrium } & \multicolumn{2}{|c|}{ Ovary } & \multicolumn{2}{|c|}{ Peritoneum } & \multicolumn{2}{|c|}{ Endometrium } & \multicolumn{2}{|c|}{ Ovary } & \multicolumn{2}{|c|}{ Peritoneum } \\
\hline & $\mathrm{N}$ & $\mathrm{E}$ & $\mathrm{N}$ & $\mathrm{E}$ & $\mathrm{N}$ & $\mathrm{E}$ & $\mathrm{N}$ & $\mathrm{E}$ & $\mathrm{N}$ & $\mathrm{E}$ & $\mathrm{N}$ & $\mathrm{E}$ \\
\hline \multicolumn{13}{|l|}{ Phase of menstrual cycle: } \\
\hline - Follicular & - & $\mathrm{H}^{7,15}$ & - & $\begin{array}{l}\mathrm{MP}^{15} \\
\mathrm{~L}^{15}\end{array}$ & - & $\begin{array}{l}\mathrm{MP}^{15} \\
\mathrm{~L}^{15}\end{array}$ & - & $\mathrm{H}^{15}$ & - & - & - & - \\
\hline - Midcycle & - & $\mathrm{H}^{7}$ & $(-)^{\mathrm{a}}$ & $\mathrm{L}^{15}$ & $(-)^{\mathrm{a}}$ & $\mathrm{L}^{15}$ & $(-)^{\mathrm{a}}$ & $\mathrm{H}^{7}$ & $(-)^{\mathrm{a}}$ & $(-)^{\mathrm{a}}$ & $(-)^{\mathrm{a}}$ & $(-)^{\mathrm{a}}$ \\
\hline - Luteal & $\mathrm{HN}^{\mathrm{a}}$ & $\mathrm{H}^{7}$ & $\mathrm{HN}^{\mathrm{a}}$ & $\mathrm{L}^{15}$ & $\mathrm{HN}^{\mathrm{a}}$ & $\mathrm{L}^{15}$ & $\mathrm{HN}^{\mathrm{a}}$ & $\mathrm{H}^{7}$ & $\mathrm{HN}^{\mathrm{a}}$ & $\mathrm{H}^{13}$ & $\mathrm{HN}^{\mathrm{a}}$ & $\mathrm{H}^{13}$ \\
\hline \multicolumn{13}{|l|}{ Endometriosis lesions: } \\
\hline - Primary & $(-)^{a}$ & $\mathrm{LN}^{\mathrm{a}}$ & - & $\mathrm{SL}^{14}$ & - & $\mathrm{SL}^{14,}$ & - & $\mathrm{LN}^{\mathrm{a}}$ & - & $\mathrm{SL}^{14,}$ & - & $\mathrm{SL}^{14,}$ \\
\hline - Recurrent & - & - & - & $\mathrm{SL}^{14}$ & & $\mathrm{SL}^{14}$ & & & & $\mathrm{ND}^{14}$ & & $\mathrm{ND}^{14}$ \\
\hline $\begin{array}{l}\text { Sampling time: } \\
\text { - Simultaneously }\end{array}$ & $(-)^{a}$ & - & - & $\mathrm{SL}^{15}$ & - & $\mathrm{SL}^{15}$ & - & - & - & $\mathrm{SL}^{15}$ & - & $\mathrm{SL}^{15}$ \\
\hline
\end{tabular}

$\mathrm{N}=$ in cases without endometriosis; $\mathrm{E}=$ in cases with endometriosis; $\mathrm{SL}=$ significantly low; $\mathrm{L}=\mathrm{Low}$; ND $=$ no difference; $\mathrm{MP}=$ more pronounced; $\mathrm{H}=$ highest; $\mathrm{HN}=$ higher but not significant; $\mathrm{LN}=$ lower but not significant; $\mathrm{PE}=$ higher PRc/ERc ratio; $(. .)^{\mathrm{n}}=$ reference number; $(. .)^{\mathrm{a}}=$ present study 
The abovementioned discrepancy can be revealed by the explanation of Kitawaki et al. ${ }^{3}$ that the endometriosis lesions not only contain ER but also aromatase, an enzyme that catalyzes the conversion of androgens to estrogens. This has suggested that local estrogen production may stimulate the growth of lesions. The expression patterns of ER and PR in endometriotic lesions are different from those in the eutopic endometrium. Moreover, estrogen metabolism, including the expression pattern of aromatase and the regulation of 17 beta-hydroxysteroid dehydrogenase type-2 (an enzyme responsible for the inactivation of estradiol to estrone), is altered in the eutopic endometrium of women with endometriosis, adenomyosis, and/or leiomyomas compared to that in the eutopic endometrium of women without disease.

Our study collected only samples within the midluteal phase of the menstrual cycle in order to obtain uniform samples. On the other hand, Bergqvist et al. ${ }^{15}$ have analyzed the levels of ERc and PRc in both endometriotic tissue and endometrium samples collected within different phases of menstrual cycle. They found that steroid cytosolic receptor levels were significantly lower in endometriotic tissue than in endometrium. The differences were most pronounced in follicular phase. In endometrium the ERc and PRc levels varied during the menstrual cycle, being highest in follicular phase. In endometriotic tissue, the estrogen receptor level remained low throughout the cycle. The PRc level increased during the menstrual cycle, being higher in luteal than in follicular phase. This cycle phase pattern was not found in the PRc level. The results show that ER and PR in endometriotic tissue have a different pattern during the menstrual cycle than endometrium and that the PR synthesized is not all biologically active. Their results indicated differences in the hormonal regulation of the two tissue types (endometrium and endometriosis).

As it has been stated earlier, ER and PR can also be measured semiquantitatively using immunohistochemical (IHC) method, which may describe their location and staining intensity in endometrium and endometriotic tissues. This technique had been applied by several investigators. ${ }^{16,18,20,21}$ Although it does not produce quantitative results, but it can clarify the receptor status and proliferative activity of eutopic and ectopic endometrium throughout the cycle, and also exclusively differentiate the nature of each type of receptor as stromal, glandular, or epithelial (Table 8). We did not use this technique in our study because we cannot apply in our future quantitative clinical and laboratory follow-ups. However we agree with the assumption that the IHC technique will be the best choice for a semiquantitative laboratory follow-up during hormonal treatment of endometriosis. ${ }^{19}$

Table 7. Comparison between the ERc and PRc contents in each tissue sample in normal (without endometriosis) and with endometriosis according to its topographic origin in several studies

\begin{tabular}{|c|c|c|c|c|c|c|c|c|}
\hline \multirow{4}{*}{$\begin{array}{c}\text { Topographic } \\
\text { origin }\end{array}$} & \multicolumn{8}{|c|}{ Positivity according to the type of cases } \\
\hline & \multicolumn{4}{|c|}{ ERc } & \multicolumn{4}{|c|}{ PRc } \\
\hline & \multicolumn{2}{|c|}{ Normal } & \multicolumn{2}{|c|}{ Endometriosis } & \multicolumn{2}{|c|}{ Normal } & \multicolumn{2}{|c|}{ Endometriosis } \\
\hline & $\%$ & $\mathrm{C}$ & $\%$ & $\mathrm{C}$ & $\%$ & $\mathrm{C}$ & $\%$ & $\mathrm{C}$ \\
\hline Endometrium & $83.3^{\mathrm{a}}$ & $608.33^{\mathrm{a}}$ & $35.71^{\mathrm{a}}$ & $99.28^{\mathrm{a}}$ & $75.0^{\mathrm{a}}$ & $599.61^{\mathrm{a}}$ & $\begin{array}{l}35.71^{\mathrm{a}} \\
100.0^{7}\end{array}$ & $21.26^{\mathrm{a}}$ \\
\hline Ovary & $100.0^{\mathrm{a}}$ & $2369.17^{\mathrm{a}}$ & $\begin{array}{l}62.5 ;^{\mathrm{a}} \\
30.0 ;^{11} 75^{7}\end{array}$ & $\begin{array}{l}512.99 ;^{\mathrm{a}} 10 \pm \\
4 ;^{11}\end{array}$ & $100.0^{\mathrm{a}}$ & $6496.42^{\mathrm{a}}$ & $43.75^{\mathrm{a}}$ & $50.64^{\mathrm{a}}$ \\
\hline Peritoneum & $100.0^{\mathrm{a}}$ & $9607.6^{\mathrm{a}}$ & $77.78^{\mathrm{a}}$ & $601.02^{\mathrm{a}}$ & $100.0^{\mathrm{a}}$ & $12466.99^{\mathrm{a}}$ & $44.44^{\mathrm{a}}$ & $\begin{array}{l}512.99, \\
1631.40^{1}\end{array}$ \\
\hline
\end{tabular}

${ }^{\mathrm{a}}$ present study; $(. .)^{\mathrm{n}}=$ reference number; normal $=$ without endometriosis 
Table 8. Comparison between the ER and PR contents determined by immunohistochemical method in each tissue sample in normal (without endometriosis) and with endometriosis according to its topographic origin in several studies

\begin{tabular}{|c|c|c|c|c|c|c|c|c|c|c|c|c|}
\hline \multirow{4}{*}{ Comparison according to } & \multicolumn{6}{|c|}{ ER-ihc } & \multicolumn{6}{|c|}{ PR-ihc } \\
\hline & \multicolumn{6}{|c|}{ Site of origin for sampling } & \multicolumn{6}{|c|}{ Site of origin for sampling } \\
\hline & \multicolumn{2}{|c|}{ Endometrium } & \multicolumn{2}{|c|}{ Ovary } & \multicolumn{2}{|c|}{ Peritoneum } & \multicolumn{2}{|c|}{ Endometrium } & \multicolumn{2}{|c|}{ Ovary } & \multicolumn{2}{|c|}{ Peritoneum } \\
\hline & $\mathrm{N}$ & $\mathrm{E}$ & $\mathrm{N}$ & $E$ & $\mathrm{~N}$ & $E$ & $\mathrm{~N}$ & $\mathrm{E}$ & $\mathrm{N}$ & $\mathrm{E}$ & $\mathrm{N}$ & $\mathrm{E}$ \\
\hline $\begin{array}{l}\text { Phase of menstrual cycle: } \\
\text { - Follicular }\end{array}$ & $\mathrm{ND}^{20}$ & - & $\mathrm{ND}^{20}$ & - & $\mathrm{ND}^{20}$ & - & $\mathrm{ND}^{20}$ & - & $\mathrm{ND}^{20}$ & - & $\mathrm{ND}^{20}$ & - \\
\hline $\begin{array}{l}\text { - Midcycle } \\
\text { - Luteal }\end{array}$ & $\begin{array}{c}- \\
\mathrm{H}^{19}\end{array}$ & $\begin{array}{c}- \\
\mathrm{H}^{20}\end{array}$ & - & $\mathrm{H}^{-}$ & - & $\mathrm{H}^{-}$ & $\begin{array}{c}- \\
\mathrm{H}^{19}\end{array}$ & - & - & $\mathrm{SH}^{-}$ & - & $\mathrm{SH}^{-}$ \\
\hline Hormonal receptor status & - & - & - & $\mathrm{NC}^{21}$ & - & $\mathrm{NC}^{21}$ & - & - & - & $\mathrm{NC}^{21}$ & - & $\mathrm{NC}^{21}$ \\
\hline Receptor score & - & - & - & $\mathrm{SC}^{16}$ & - & $\mathrm{SC}^{14}$ & - & - & - & $\mathrm{NC}^{14}$ & - & $\mathrm{NC}^{16}$ \\
\hline Receptor concentration & - & $\mathrm{SC}^{18}$ & - & $\mathrm{ND}^{18}$ & - & $\mathrm{ND}^{18}$ & - & $\mathrm{SC}^{18}$ & - & $\mathrm{ND}^{18}$ & - & $\begin{array}{l}\mathrm{H}^{17} \\
\mathrm{ND}^{18}\end{array}$ \\
\hline Endometriosis lesions: & & & & & & & & & & & & \\
\hline - Primary & - & - & - & - & - & - & - & - & - & $\mathrm{L}^{20}$ & - & $\mathrm{L}^{20}$ \\
\hline - Recurrent & - & - & - & - & - & - & - & - & - & - & - & - \\
\hline Stage of endometriosis: & - & - & - & $\mathrm{NC}^{21}$ & - & $\mathrm{NC}^{21}$ & - & $\mathrm{NC}^{21}$ & - & $\mathrm{NC}^{21}$ & - & $\mathrm{NC}^{21}$ \\
\hline Location of receptor: & & & & & & & & & & & & \\
\hline - Epithelial & - & $\mathrm{L}^{16}$ & - & $\begin{array}{l}\mathrm{L}^{16} \\
\mathrm{SH}^{17}\end{array}$ & - & $\begin{array}{c}\mathrm{L}^{16} \\
\mathrm{SH}^{17}\end{array}$ & - & $\mathrm{SL}^{16}$ & - & $\mathrm{SL}^{16,20}$ & - & $\mathrm{SL}^{16,20}$ \\
\hline - Glandular & - & - & - & - & - & - & - & - & - & - & - & - \\
\hline - Stromal & - & $\mathrm{ND}^{16}$ & - & $\begin{array}{l}\mathrm{ND}^{16} \\
\mathrm{SH}^{20}\end{array}$ & - & $\begin{array}{l}\mathrm{ND}^{16} \\
\mathrm{SH}^{20}\end{array}$ & - & $\mathrm{ND}^{17}$ & - & $\begin{array}{l}\mathrm{ND}^{17} \\
\mathrm{SL}^{19}\end{array}$ & - & $\begin{array}{l}\mathrm{ND}^{17} \\
\mathrm{SL}^{20}\end{array}$ \\
\hline
\end{tabular}

ihc $=$ immunohistochemical; $(. .)^{\mathrm{n}}=$ reference number; $\mathrm{NC}=$ no correlation; $\mathrm{ND}=$ no difference; $\mathrm{N}=$ in cases without endometriosis; $\mathrm{E}=$ in cases with endometriosis; $\mathrm{H}=$ highest; $\mathrm{HN}=$ higher but not significant; $\mathrm{SC}=$ significant correlation; $\mathrm{SH}=$ significantly higher; $\mathrm{SL}=$ significantly lower; $\mathrm{L}=$ Low; $\mathrm{MP}=$ more pronounced; $\mathrm{LN}=$ lower but not significant; $\mathrm{PE}=$ higher $\mathrm{PRc} / \mathrm{ERc}$ ratio; $(-)=$ no data found

\section{The PRc/ERc ratio in relationship with the prospect of hormonal therapy of endometriosis}

It is appeared in our study that normal endometrium contained PRc 4.6-folds higher than ERc, whereas the normal ovary contains PRc 27.8-folds higher than ERc. However, the normal peritoneum contains ERc 2.2-folds higher than PRc. It is particularly interested that the significant and highest PRc/ERc ratio occurs in the endometriotic peritoneal tissue (Table 5), whereas in normal tissue the significant and highest $\mathrm{PRc} / \mathrm{ERc}$ ratio is found in the ovary. This data may lead us to suggest that peritoneum is the most responsive type of tissue to hormonal (e.g. progesterone) therapy, while the normal ovary is the most concomitantly affected type of normal tissue to progesterone therapy.

The ratio between PRc and ERc was also considered by Lyndrup et al. ${ }^{7}$ and they found significantly higher
$\mathrm{PRc} / \mathrm{ERc}$ ratios in the cytosol of endometriotic tissue. Thus, they concluded that the lower receptor concentrations found in endometriosis cannot be explained solely as ectopic endometrium being diluted by non receptor-containing tissue. In spite of high PRc/ERc ratios in endometriosis, they also encountered significant secretory changes similar to those found in endometrium.

The above revealed facts lead us to estimate that when the abnormal tissue is treated hormonally, no specific response can be obtained. In addition, the hormonal treatment given to the endometriosis patients can also attack the cells in normal tissue because they also contained the similar sex steroid hormone (estrogen and progesterone) receptors. This will particularly affect the peritoneum. 


\section{CONCLUSIONS}

The ovarian sex steroid (estrogen and progesterone) hormone receptors concentration in the endometriotic tissue is lower than that in the normal tissue, but there is no significant difference of between each tissue according to its same topographic origin.

Our results may assume that the responsivity on hormonal treatment in endometriosis cases will depend on the sex steroid receptor content in the sick tissues, and the peritoneal lesions will possibly give better response than those in other sites. The quantitative method of ERc and PRc measurement might be used a quantitative tool for laboratory follow-ups during hormonal treatment of endometriosis. A further clinical trial is necessary.

\section{REFERENCES}

1. Wheeler JM. Epidemiology of endometriosis-associated infertility. J Reprod Med 1989;34:41-6

2. Eskenazi B, Warner ML. Epidemiology of endometriosis. Obstet Gynecol Clin North Am 1997;24:235-58

3. Kitawaki J, Kado N, Ishihara H, Koshiba H, Kitaoka Y, Honjo H. Endometriosis: the pathophysiology as an estrogen-dependent disease. J Steroid Biochem Mol Biol 2002; 83(1-5):149-55

4. Strauss III J, Coutifaris C. The endometrium and myometrium: regulation and dysfunction. In: Yen SSC, Jaffe RB, Barbieri R, eds. Reproductive endocrinology, $4^{\text {th }}$ ed. Philadelphia: WB Saunders Co. 1999; 218-56

5. Levy C, Robel P, Gautray JP, De Brux J, Verma U, Descomps B, Baulieu EE. Estradiol and progesterone receptors in human endometrium: normal and abnormal cycles and pregnancy. Am J Obstet Gynecol 1980; 136:646-51

6. Lessey BA, Killam AP, Metzger DA, Haney AF, Greene GL, McCarty Jr KS Immunohistochemical analysis of human uterine estrogen and progesterone receptors throughout the menstrual cycle. J Clin Endocrinol Metab $1988 ; 67: 334-40$

7. Lyndrup J, Thorpe S, Glenthoj A, Obel E, Sele V. Altered progesterone/estrogen receptor ratios in endometriosis. A comparative study of steroid receptors and morphology in endometriosis and endometrium. Acta Obstet Gynecol Scand 1987;66(7):625-29

8. Howell RJ, Dowsett M, Edmonds DK. Oestrogen and progesterone receptors in endometriosis: heterogeneity of different sites. Hum Reprod 1994;9:1752-8
9. Berqvist A, Ljungberg O, Myhre E. Comparison of histological appearance of human endometrium and endometriotic tissue ob-tained simultaneously. Acta Obstet Scand Suppl 1984;123:11-2

10. Berqvist A, Carlström K, Jeppsson S, Ljungberg O. Histochemical localization of specific estrogen and progesterone binding in human endometrium and endometriotic tissue. Acta Obstet Scand Suppl 1984;123:15-6

11. Lowry OH, Rosenborgh NJ, Farr AL, Randal RJ. Protein measurements with folin phenol reagent. J Biol Chem 1951;193:265-75

12. Berqvist, A. Steroid receptors in endometriosis. In: Thomas E. and Rock J. (eds). Modern Approach to Endometriosis. Dordrecht: Kluwer, 1991;33-5

13. Bergqvist A, Rannevik G, Thorell J. Estrogen and progesterone cytosol receptor concentration in endometriotic tissue and intra-uterine endometrium. Acta Obstet Gynecol Scand Suppl 1981;101:53-8

14. Bergqvist A, Ferno M. Estrogen and progesterone receptors in endometriotic tissue and endometrium: comparison according to localization and recurrence. Fertil Steril 1993;60(1): 63-8

15. Bergqvist A, Ferno M. Oestrogen and progesterone receptors in endometriotic tissue and endometrium: comparison of different cycle phases and ages. Hum Reprod 1993;8(12): 2211-7

16. Bergqvist A, Ljungberg O, Skoog L. Immunohistochemical analysis of oestrogen and progesterone receptors in endometriotic tissue and endometrium. Hum Reprod 1993;8(11): 1915-22

17. Bergqvist A, Jeppsson S, Kullander S, Ljungberg O. Human uterine endometrium and endometriotic tissue transplanted into nude mice. Morphologic effects of various steroid hormones. Am J Pathol 1985;121(2):337-41

18. Lessey BA, Metzger DA, Haney AF, McCarty KS Jr. Immunohistochemical analysis of estrogen and progesterone receptors in endometriosis: comparison with normal endometrium during the menstrual cycle and the effect of medical therapy. Fertil Steril 1989; 51(3):409-15

19. Nisolle M, Casanas-Roux F, Wyns C, de Menten Y, Mathieu PE, Donnez J. Immunohistochemical analysis of estrogen and proges-terone receptors in endometrium and peritoneal endometriosis: a new quantitative method. Fertil Steril 1994;62(4):751-9

20. Jones RK, Bulmer JN, Searle RF. Immunohistochemical characterization of proliferation, oestrogen receptor and progesterone receptor expression in endometriosis: comparison of eutopic and ectopic endometrium with normal cycling endometrium. Hum Reprod 1995;10(12):3272-9.

21. Regidor PA, Regidor M, Metz KA, Schindler AE. Immunohistochemical detection of estrogen and progesterone receptors in endometriotic tissue. A comparative study of paraffin embedded and fresh frozen tissues. Arch Gynecol Obstet 1994;255 (4):181-7. 